\title{
UNDERSTANDING THE DIMENSIONS OF MANAGERIAL DECENCY CONSTRUCT
}

\author{
Belma Hadžiomerović* \\ Emir Kurtic ${ }^{* *}$ \\ Maja Arslanagić-Kalajdžicic**
}

Received: 5.3. 2021

Preliminary communication

Accepted: 31. 5. 2021

UDC 005.32,

DOI https://doi.org/10.30924/mjcmi.26.1.4

159.944:005

\begin{abstract}
This study aims to improve the understanding of perceived managerial decency by developing an initial set of items for its measurement scale. Based on the social exchange theory and driven by the strong need for instilling more decency and civility in managerial discourse, this study makes a comprehensive overview of the scope and domain of perceived managerial decency and extracts the potential decency dimensions. After conducting a literature review, 50 collected interview responses on typical examples of managerial decency, as perceived by employees, served as a basis for further analysis. Using the content analysis tools, we generated a set of initial items and dimensions
\end{abstract}

Abstract

\section{INTRODUCTION}

Due to the stronger emphasis on relationships as vehicles of business success (PwC, 2021) managerial skills and behavior exhibit a more pronounced role in today's business. Dealing with people, an adequate way of communication comes to the forefront in the "new normal" and tends to initiate a lasting change in how employees are of decency. Those were further refined by 21 experts (5 from academia and 16 from the target audience) using the means of qualitative and quantitative assessment. As a result, we define the perceived managerial decency construct and outline its six potential dimensions: (1) respectful interactions, (2) treatment with good manners, (3) employee development, (4) mutual trust, (5) decent feedback, and (6) providing insight into a bigger picture, as well as generate a set of 75 valid items that reflect the decency construct. We further discuss the research implications for theory and practice.

Keywords: managerial decency, qualitative research, scale development

lead (Meck, 2020) which all brings us to the importance of one vital aspect of leadership - and that is - decency. In today's complex work environment, it is incredibly difficult to recognize what makes a good manager and leader. Does it all come down to a power motive (Trojak \& Galić, 2020; Pfeffer, 2013)? Recent practitioner studies show that for managers and leaders, decency is just as important as intelligence (Boulding,

\footnotetext{
* Belma Hadžiomerović, Raiffeisen BANK BiH, Zmaja od Bosne bb, 71000 Sarajevo, Bosnia \& Herzegovina, Phone: +38733287452, +38733287304, E-mail: belma.hadziomerovic@raiffeisengroup.ba

** Emir Kurtić, School of Economics and Business, University of Sarajevo, Trg oslobođenja - Alija Izetbegović 1, 71000 Sarajevo, Bosnia \& Herzegovina, Phone: +38733275917 / +38733275906, E-mail: emir.kurtic@efsa.unsa.ba, ORCID: https://orcid.org/0000-0002-4846-7991

*** Maja Arslanagić-Kalajdžić (corresponding author), School of Economics and Business, University of Sarajevo, Trg oslobođenja - Alija Izetbegović 171000 Sarajevo, Bosnia \& Herzegovina, Phone: +38733253883/ +38733275906, E-mail: maja.arslanagic@efsa.unsa.ba, ORCID: https://orcid.org/0000-0002-4954-782X
} 


\section{Journal of Contemporary Management Issues}

2019). Leading with decency means genuinely caring about employees' wellbeing. It means empathizing with and genuinely caring for those being lead. Just like emotional quotient (EQ) and intelligence quotient (IQ), according to Boulding (2019) decency quotient (DQ) is a measure of a manager's capability to lead. However, decency is still very rarely recognized as one of the essential qualities in business (both by researchers and practitioners). This is shown by estimates that businesses lose $\$ 6$ billion per year due to hostile work environments created by behavior such as managerial incivility and related negative interactions (Porath, Gerbasi, \& Schorch, 2015). Incivility dominates business relationships (Leiter et al., 2011; Pearson, Andersson, $\&$ Porath, 2005) and efficient interventions are hence required to improve the quality of work relationships.

Decency is an act or expression of genuine care (Harrison, 2007), but the question is - whether it pays off to managers and leaders to be decent in the workplace environment. Due to its formal character, civility is related and much more defined and explored construct in managerial literature. Namely, Carter (1998) suggests that civility is the moral foundation necessary for human interactions and that civility begins with the attitude of respect for others, as well as that it gains in importance when interactions are more complex and frequent (such as in the workplace environment). Kimbroigh and Burkett (1990) state that good, efficient administrators are lead by the example of their civility and good manners. Civility operates in line with the work norms and includes good manners and respect for others in the workplace (Anderson \& Pearson, 1999).

However, if, apart from being civil (courteous, aware of the rights of others;
Elias, 1982; Carter, 1998; Morris et al., 1996), managers utilize the approach towards their employees that encompasses dignity, appreciation, and true care, they are then assumed to be decent. Although they are often used interchangeably, the terms decency and civility are not synonymous. Namely, as it is outlined above, decency is reflected by behavior that is not only reflecting socially acceptable norms but rather showing true care and empathy for others, while civility essentially means behavior through which norms and standards of mutual respect are expressed (Lauer, 2002). Namely, unlike civility, "decency carries an element of essential soulcraft to it: It goes deeper, into character more than manners" McNemee (2018). Sometimes a civil person can be cruel, while a decent person is never so since decency goes back to moral and ethical rightness and wrongness of a certain thought and action, whereas civility is ignoring such aspects (McNemee, 2018).

Managerial decency ensures dignity and decency at work, and consequently, it is related to equal opportunities, social security and protection, and ultimately to the quality-of-life concept (Faioli, 2009). Decency is further a part of the quality of relationships in the workplace (Blustein et al., 2016; Di Fabio \& Kenny, 2016; Kenny et al., 2016) and hence could be seen through the lens of mutual relationships and social exchange theory (SET; Blustein, 2011). The following could be seen as the needs of individuals related to work: the need for social connection; the need for power (Trojak \& Galić, 2020); and the need for self-determination (Blustein, 2011). The SET theory is based on the so-called unwritten or psychological contract (Schein, 1978).

The effects of managerial decency at the workplace have gained theoretical attention. However, since there is a lack of reliable 
operationalization and measure of this construct, empirical research remains scarce. Researchers have been more focused on measuring and operationalization of uncivil or non-decent behavior. Therefore, the objective of this paper is to propose a comprehensive measurement scale for that since it will examine the potential dimensionality of the concept of decency by using the premises of the SET theory. Although there are already several measurement scales in the field of organizational psychology and leadership, such as interactional justice (Moorman, 1991; Scarlicki \& Folger, 1997), civility (Ferris, 2002), workplace relational civility (Di Fabio \& Gori, 2016), we argue that perceived decency is related but not the same concept and that it should be put into the spotlight due to its practical relevance for present-day managers and leaders (being at the same level as emotional intelligence and cognitive intelligence).

Following a detailed literature search through Web of Science (search string: "decency"; field "Topic" including the title of the paper, summary, and keywords of the paper), it has been established that the perceived decency scale is non-existent. The result set of 353 scientific articles has been further searched by the use of the word "scale" in all fields. There have been 9 results of this search, of which only one is related to the measurement scale (Di Fabio \& Gori, 2016). Then, the contents of potentially related scales derived from the literature review (e.g., Walsh et al., 2012; Anker et al., 2003) were analyzed as well (as it will be seen consequently) and it has been established that they do not explicitly measure decency.

The contribution of this study is twofold. First, as an answer to the recognition of the importance of decent and civil behavior of managers in the literature, this study presents a review of previous studies and offers a novel conceptualization of perceived managerial decency. Within this conceptualization, we provide a new definition of the concept and elaborate on its potential dimensions. Second, to boost additional empirical research on the decency construct, we develop a broad set of items for the potential scale that will measure managerial decency, which reflects not only normative and civil behavior, but also true care and empathy of managers. We utilize qualitative research methods and by conducting interviews with target public as well as through the help of experts, we isolate a broad set of items that are aligned with the definitional landscape and scope of the managerial decency concept.

The paper is organized as follows. In the next chapter, we will present a literature review that revolves around the concept of decency and that was used as a theoretical basis for scale development. Then, we will present the methods and consequent two studies that outline the process of item generation and theoretical evaluation and validation of the items. Two studies result in the final proposal of the instrument for perceived managerial decency that is prepared for empirical verification. Conclusions based on the analysis, as well as theoretical and managerial implications, are presented in the final section.

\section{LITERATURE REVIEW}

The context of communication, connections, and relationships implies necessary (positive or negative) social exchanges at work (Porath, Gerbasi, \& Schorch, 2015; Griffin, Stoverink, \& Gardner, 2012; Dutton, 2003). Namely, in performing complex tasks, employees often seek exchanges from others in the form of expert opinion, 


\section{Journal of Contemporary Management Issues}

knowledge, energy, and/or experience. Social exchange theory (SET) is one of the most influential theoretical paradigms explaining workplace behaviors (Cropanzano \& Mitchell, 2005) and a theoretical base for this study. SET assumes reciprocity and justice. Namely, the norm of reciprocity (Gouldner, 1960) explains that giving and receiving are mutually contingent and that reciprocity refers to attitudes and actions. Then, SET is an anchor for the organizational justice propositions (Greenberg, 1990). There are four dimensions of organizational justice which are based on the assessments of the extent to which decision-making in firms is equitable and just (distributive justice, process, justice, interpersonal justice, and information justice; Colquitt, 2001; Colquitt et al., 2013).

Philosophically, decency is strongly rooted in assessments of morality such as Heller's (1990), who even claims that morality survives due to the existence of decent individuals. Based on this premise, Macklin (2007, p. 272) claims that "morality exists because decent people exist, and decent people exist because they have made an existential choice to suffer wrong if faced with the alternative of committing wrong". In this view, decency is then not seen as uncritical acceptance of norms and values in a certain (organizational) culture, but due to the true preference of decent individuals to follow moral norms. We explore the role that decency, understood in this way, has in workplace exchanges, guided by the SET paradigm.

Boulding (2019) is the one that stands for the premise that decency is as important as intelligence (both general and emotional) for leaders. Decency "means wanting something positive for everyone in the workplace and ensuring everyone feels respected and valued" (Boulding, 2019) and it is argued that decency should be recognized as one of the desired qualities of good leaders. Furthermore, in his book, Harrison (2007) claims that decency consists of small, positive acts of leaders that build great organizational cultures. However, any additional aspects of managerial decency are off the radar of scientific research. Therefore, we here capture the main aspects and findings that are related to civility and incivility at work and relate them to decency. Namely, we argue that if civility is good and desired, then decency is even better and even more desired in the workplace environment since it is a completely different level of morally guided behavior and not just a formal adherence to norms.

At work, respectful treatment is what everyone anticipates (Cortina, 2008). However, there are still many employees who report incivility (Pearson et al., 2005). Rude social exchanges inhibit such interactions thus wasting valuable resources of knowledge and potential. Civility assumes respect (Leiter et al., 2011; Herzberg, Mausner, \& Snyderman, 1959) while incivility represents rude actions (Anderson \& Pearson, 1999). Both civility and incivility impact various employee- and organization-level constructs such as productivity, performance, creativity, retention (Bies \& Tripp, 2005; Porath \& Erez, 2007, Lim, Cortina \& Magley, 2008) with incivility causing very negative outcomes such as stress, anxiety, depression or burnout (Agervold \& Mikkelsen, 2004; Leiter et al., 2011; Leiter \& Maslach, 2009; Yamada, 2000).

Managers who are civil and decent are often perceived as "too nice". This is in many organizational cultures (and cultures in general) perceived as a weakness and being nice is often found to be in negative correlation with influence, power, and 
- ultimately - income (Forni 2002; Judge, Livingston, \& Hurst, 2012). However, the latter mostly depends upon the level up to which the civility/incivility is established within a group - is it strong enough to become the norm and part of the culture (Leiter et al., 2011). Porath, Gerbasi, and Schorch (2015) find that ones who are civil perform better in a group, mainly since other individuals seek those who are civil for advice and see them as leaders. This is one of the rare studies that contribute to the argument that "through civility, people may be perceived as leaders" (Porath, Gerbasi \& Schorch, 2015; p. 1536).

Civil behavior establishes links (Dutton, 2003; Hallowell, 1999) and inspires positive emotions (Porath, Gerbasi \& Schorch, 2015) inciting possibilities for relationships and benefits which come due to rooted behavior (Lawler, 2001). Decency embodies warm, friendly, other-oriented behaviors. A psychological mechanism of mirroring (Cooley, 1992) comes into place in such situations since individuals tend to use selfexpression, behaviors, and reactions to the behavior of others in defining their expressions and actions (Roberts, 2007). By making people feel valued, decency has the potential to lift them high up and it enables the creation and nurturing of relationships. Consequently, by engaging respectfully and decently with others, managers will have the possibility to build stronger relationships and form networks out of them (Cross \& Parker, 2002) since the networking capability is one of the key leadership traits.

Managerial decency needs to be distinguished from similar constructs and behaviors. For example, unlike organizational citizenship behaviors (OCBs), decency does not necessarily involve the intent to benefit the organization (Anderson \& Pearson, 1999). Furthermore, although one of the four dimensions of organizational justice is interpersonal justice which assumes interpersonal communication and exchanges (Colquitt et al., 2013). By carefully examining its domain and content, we can observe that interpersonal justice reflects the perceptions of (in)civility in the interpersonal relationships by using formal norms while decency - with the aspect of true care for the other - is not the part of the observed interpersonal process.

\section{METHODOLOGY}

To understand managerial decency better, we have ventured into a complex procedure of scale development (DeVellis, 2003; Nunnally 1967). This procedure is varying in several phases and steps, but it can be explained through three general steps: (1) item generation, (2) theoretical analysis, and (3) psychometric analysis. To develop a scale for a certain latent construct, a researcher needs to generate a pool of items (Step 1), assess the content of the generated items (Step 2), and empirically assess the reliability and validity of the generated items that finally become a measurement scale (Step 3). In this study, we present steps 1 and 2 of the process, while Step 3 is out of the scope of the paper.

We approach the first two steps through two studies. Study 1 , where we have used both deductive (based on a literature review) and inductive (based on qualitative research) methods of item generation (Hinkin, 1995; Hutz et al., 2015; Uzunboylu \& Ozdamli 2011) to generate the initial set of items, and Study 2, where we processed the generated items in a way to ensure that they reflect the perceived managerial decency construct (Arias et al., 2014) with its content, and meaning. For these purposes, a pool of expert and target 


\section{Journal of Contemporary Management Issues}

population judges was used (Nunnally 1967). Step 3, as the final step of scale development, includes conducting a series of quantitative studies and analyzing various aspects of statistical validity and reliability of the generated items, and this is what we recommend for further research.

\section{RESULTS}

\subsection{Study 1: Perceived managerial decency item generation}

The literature review should be considered an initial and necessary deductive step founded for the new scale development. At the same time, it serves to explain the nature and diversity of the targeted construct content. In addition, literature reviews help in identifying the existing measures that may be used as a reference for the development of new scales (Morgado et al., 2017; DeVellis 2003). This paper uses the method of systematic literature review that enables the identification and systematization of topics that create the domain of the certain object of research (Munoz-Leiva, SanchezFernandez Liebana-Cabanillas, and LopezHerrera, 2013). Also, the Content Analysis / Thematic Analysis was used and is focused on revealing and noting certain contents within the researched material; thus, such analysis was carried out to identify the potentially important statements that need to be included in the new scale.

The first phase of the scale development process included the development of a set of items that are conceptually following the theoretical domain of civility. Defining the perceived managerial civility construct started with the relevant literature review and a clear understanding of the construct domain. A detailed review of scales was made with the belonging items which measure incivility/civility, decency, and 16 selected scales that were considered and presented in Table 1.

Table 1. Scales from literature, identified as relevant for perceived managerial decency

\begin{tabular}{|l|l|l|l|}
\hline$\#$ & \multicolumn{1}{|c|}{ Scale } & \multicolumn{1}{c|}{ Author(s) } & \multicolumn{1}{c|}{ Description } \\
\hline 1 & $\begin{array}{l}\text { Interactional } \\
\text { Justice Scale }\end{array}$ & (Moorman, 1991) & $\begin{array}{l}\text { This is one of the first measures of justice and it is related } \\
\text { to citizenship behavior. Focused on the framework and } \\
\text { trends of justice in interactions. }\end{array}$ \\
\hline 2 & $\begin{array}{l}\text { Petty Tyrant } \\
\text { Scale }\end{array}$ & (Ashforth, 1997) & $\begin{array}{l}\text { Encompasses the domain of personal aggression and } \\
\text { political deviations. Three of the six dimensions are in } \\
\text { accordance with the political deviation. Effects of petty } \\
\text { tyranny included frustration, stress, reactance, helpless- } \\
\text { ness, and work alienation among subordinates. }\end{array}$ \\
\hline 3 & $\begin{array}{l}\text { Abusive } \\
\text { Supervision }\end{array}$ & (Tepper, 2000) & $\begin{array}{l}\text { Characterized by abuse of position, the routine pattern of } \\
\text { intentional and repetitive hostile verbal and non-verbal } \\
\text { behavior, which is not a physical assault but highly unac- } \\
\text { ceptable by society. }\end{array}$ \\
\hline 4 & $\begin{array}{l}\text { Measure of } \\
\text { Bulkplace }\end{array}$ & $\begin{array}{l}\text { Victims of bullying report significantly lower levels } \\
\text { of dissatisfaction with work. Furthermore, they report } \\
\text { significantly higher levels of anxiety, depression, and } \\
\text { tendency to departure than those who have no such } \\
\text { experience. }\end{array}$ \\
\hline
\end{tabular}




\begin{tabular}{|c|c|c|c|}
\hline$\#$ & Scale & Author(s) & Description \\
\hline 5 & $\begin{array}{l}\text { Workplace } \\
\text { Incivility Scale }\end{array}$ & $\begin{array}{l}\text { (Cortina et al., } \\
\text { 2001) }\end{array}$ & $\begin{array}{l}\text { Analyses experiences related to negative behaviors at the } \\
\text { workplace in the last five years. How conflict is managed } \\
\text { affects the process and outcome of a conflict. It explores } \\
\text { the relationship between conflict management styles and } \\
\text { workplace incivility. }\end{array}$ \\
\hline 6 & Civility & (Ferris, 2002) & $\begin{array}{l}\text { Four essential questions for the study of civility involve } \\
\text { developing a definition of the term, determining } \\
\text { its effects, establishing trends, and predicting the } \\
\text { consequences of civility. A framework for studying it } \\
\text { includes the actors, their gender, situations and settings, } \\
\text { occupational role requirements, the cultural imperatives } \\
\text { defining civility, and the processes through which it is } \\
\text { learned. }\end{array}$ \\
\hline 7 & Incivility & (Crocker, 2005) & $\begin{array}{l}\text { The measure of incivility in this research encompassed } \\
21 \text { items. Such measuring resulted in } 4 \text { subcategories that } \\
\text { include a richer and broader spectrum of uncivil behavior. }\end{array}$ \\
\hline 8 & $\begin{array}{l}\text { Uncivil } \\
\text { Workplace } \\
\text { Behavior }\end{array}$ & $\begin{array}{l}\text { (Martin \& Hine, } \\
\text { 2005) }\end{array}$ & $\begin{array}{l}\text { Describes the development and valuing of the new } \\
\text { measurement of workplace incivility - questionnaire on } \\
\text { uncivil workplace behavior. Scale that asks participants to } \\
\text { report how frequently they experienced behaviors (from } \\
\text { an unspecified source) such as raised voices, eye-rolling, } \\
\text { being interrupted, being excluded, and being gossiped } \\
\text { about at work during the past year. }\end{array}$ \\
\hline 9 & Civility & $\begin{array}{l}\text { (Meterko et al., } \\
\text { 2007) }\end{array}$ & $\begin{array}{l}\text { The civility scale measures the perception of civility } \\
\text { within the workgroup and the organization. The scale } \\
\text { measures the aspects of workplace civility through the as- } \\
\text { sessment of employees according to personal interest and } \\
\text { respect by peers, cooperation or teamwork in the work- } \\
\text { group, fair conflict resolution, and valuing of individual } \\
\text { differences by peers and supervisors. }\end{array}$ \\
\hline 10 & $\begin{array}{l}\text { Perceived } \\
\text { Workplace } \\
\text { Civility Climate }\end{array}$ & (Ottinot, 2008) & $\begin{array}{l}\text { This scale assesses the extent to which employees per- } \\
\text { ceive the importance an organization places upon manag- } \\
\text { ing and preventing acts of incivility and verbally aggres- } \\
\text { sive actions in the workplace. The scale encompasses } \\
\text { three dimensions: (1) Intolerance, (2) Response, and (3) } \\
\text { Policies and Procedures. }\end{array}$ \\
\hline 11 & Civility norms & $\begin{array}{l}\text { (Walsh et al., } \\
\text { 2012) }\end{array}$ & $\begin{array}{l}\text { Intended for the estimate of an atmosphere of civility of } \\
\text { the workgroup. The atmosphere of civility is defined as } \\
\text { a perception of employees of the norms which support } \\
\text { the treatment of respect among the members of the work- } \\
\text { group. }\end{array}$ \\
\hline
\end{tabular}




\section{Journal of Contemporary Management Issues}

\begin{tabular}{|c|c|c|c|}
\hline \# & Scale & Author(s) & Description \\
\hline 12 & $\begin{array}{l}\text { Organizational } \\
\text { Civility Scale }\end{array}$ & $\begin{array}{l}\text { (Clark, Landrum \& } \\
\text { Nguyen, 2013) }\end{array}$ & $\begin{array}{l}\text { Measures the perception of employees of civility, stress, } \\
\text { facing different situations, work satisfaction, level to } \\
\text { which the incivility is experienced as a problem, factors } \\
\text { which contribute to that, and possibilities for problem re- } \\
\text { solving. Able to predict the organizational civility, includ- } \\
\text { ing items that relate to respect, fellowship, content with } \\
\text { Supervisors, workplace environment, civility expressed } \\
\text { through mission/vision, emotionalism in the coping strate- } \\
\text { gies, and frequency of abuse of power. }\end{array}$ \\
\hline 13 & $\begin{array}{l}\text { SET Indicators } \\
\text { Scale }\end{array}$ & $\begin{array}{l}\text { (Coloquitt et al., } \\
\text { 2014) }\end{array}$ & $\begin{array}{l}\text { Perceived support, exchange quality, affective commit- } \\
\text { ment, trust, and psychological contract fulfillment were } \\
\text { used as indicators of social exchange relationships. } \\
\text { Through the quantitative approach to content validation, } \\
\text { these dimensions were assessed. }\end{array}$ \\
\hline 14 & $\begin{array}{l}\text { Incivility } \\
\text { Atmosphere Scale } \\
\text { at the Team Level }\end{array}$ & $\begin{array}{l}\text { (Paulin \& Griffin, } \\
2015 \text { ) }\end{array}$ & $\begin{array}{l}\text { Identifies the incivility atmosphere as a new specific } \\
\text { aspect of atmosphere construction. Referring to divided } \\
\text { perceptions of uncivil behavior, practice, and norms that } \\
\text { exist within a team, incivility atmosphere construction is } \\
\text { fundamental for future research which assesses the effect } \\
\text { of incivility at the level of the work team. }\end{array}$ \\
\hline 15 & $\begin{array}{l}\text { Workplace } \\
\text { Relational } \\
\text { Civility }\end{array}$ & $\begin{array}{l}\text { (Di Fabio \& Gori, } \\
\text { 2016) }\end{array}$ & $\begin{array}{l}\text { Multidimensional scale based on cultural relational theory } \\
\text { which explains workplace interpersonal relationships and } \\
\text { the resulting atmosphere. The scale has three dimensions } \\
\text { with a good internal consistency: relational decency, } \\
\text { relational culture, and relational readiness and measures } \\
\text { them in the "mirror" form. }\end{array}$ \\
\hline 16 & $\begin{array}{l}\text { Academic } \\
\text { Relational } \\
\text { Civility }\end{array}$ & $\begin{array}{l}\text { (Di Fabio \& } \\
\text { Kenny, 2016) }\end{array}$ & $\begin{array}{l}\text { Revealing the perception of academic relational civility } \\
\text { facilitates the reduction of bias in the assessment process. } \\
\text { The scale has three dimensions, as well as the workplace } \\
\text { relational civility scale: relational decency, relational } \\
\text { culture, and relational readiness. }\end{array}$ \\
\hline
\end{tabular}

Scales from the literature, as noted above, are used in the process of item generation. For the item to be included, we assessed whether it is related to decency as the construct of interest. Descriptions of decency were taken into consideration to better define the scope of the domain.

Consequently, a qualitative study was conducted to gain insights from the target population on what decency means for them. Employees and managers in three hierarchy levels were invited to participate in the process of item generation. The requirement for participation was that an interviewee had been employed in the previous six-month period. We used a semi-structured interview mode and asked participants to focus on "managerial decency", and then to describe the behavior - what managerial decency means for them, as well as to provide up to five examples of perceived managerial decency. A set of 50 interviews was conducted and based on them, 242 individual examples were obtained about 
their perceptions of decency. Table 2 shows the demographic characteristics of the interviewees.

Table 2. Interviewees' characteristics

\begin{tabular}{|l|l|l|l|}
\hline Characteristic & Percentage & Characteristic & Percentage \\
\hline Sex & & Education & \\
\hline Male & $38 \%$ & High school & $6 \%$ \\
\hline Female & $62 \%$ & Bachelor & $44 \%$ \\
\hline & & Master or above & $50 \%$ \\
\hline Age & & Work experience & \\
\hline $18-35$ & $26 \%$ & Less than 10 years & $20 \%$ \\
\hline $36-50$ & $66 \%$ & $11-20$ years & $66 \%$ \\
\hline $51-65$ & $8 \%$ & More than 20 years & $14 \%$ \\
\hline
\end{tabular}

We examined all 242 examples to recognize the pattern of repetition of words or phrases which describe perceived decent managerial behavior. We classified similar examples and traits based on the terminology and descriptors. For example, we identified that the term "respect" is repeated 18 times; "appreciation" 11 times, etc. After all cases and behaviors were examined, behaviors were grouped, where appropriate, in potential dimensions of perceived decency. Thesaurus was used for the management of grouping and the expressions, such as respect and appreciation, development, trust, and support were used as working names for the generic set of behaviors. To develop a suitable set of items, the list of items was reduced according to frequency. To develop the generic set of behaviors, it is reasonable to accept the frequency of phenomenon as a decisive factor in further reduction of items, concluding that such frequency is a reasonable indication of the importance of the content of interest (DeVellis, 2003).

As a result of the above-described process, we obtained seven dimensions of perceived managerial decency (Table 3). Those dimensions are (1) Respectful Interactions, (2) Treatment with Good Manners, (3) Employee Development, (4) Mutual Trust, (5) Decent Feedback, (6) Providing insight into Bigger Picture and (7) Active Listening.

Table 3. Dimension of decency based on research

\begin{tabular}{|l|l|}
\hline Generated dimension & Content description \\
\hline Respectful Interactions & $\begin{array}{l}\text { Respect; Openness for other ideas; Helpfulness; } \\
\text { Compassion; Appreciation; }\end{array}$ \\
\hline Treatment with Good Manners & $\begin{array}{l}\text { Courtesy; Good manners; Punctuality; Greetings; } \\
\text { Mindfulness; Smile; }\end{array}$ \\
\hline Employee Development & $\begin{array}{l}\text { Motivation; Support; Driver; Teamwork; } \\
\text { Encouragement; Fairness in task assignment; Equal } \\
\text { treatment; }\end{array}$ \\
\hline
\end{tabular}




\section{Journal of Contemporary Management Issues}

\begin{tabular}{|l|l|}
\hline Mutual Trust & $\begin{array}{l}\text { Reliance; Protection; Consistency; Effort; Reliability; } \\
\text { Credibility; Transparency; }\end{array}$ \\
\hline Decent Feedback & $\begin{array}{l}\text { Learning from mistakes; Public praise; } \\
\text { Comprehensibility; Patience; Reproach in private; }\end{array}$ \\
\hline Providing insight into Bigger Picture & $\begin{array}{l}\text { Providing context; Justifying tasks; Sharing } \\
\text { information; Knowledge transferring; }\end{array}$ \\
\hline Active Listening & $\begin{array}{l}\text { Self-control; Eye contact; Not interrupting; Expressing } \\
\text { thoughts and emotions in a straightforward, frank, and } \\
\text { socially acceptable manner; }\end{array}$ \\
\hline
\end{tabular}

The resulting dimensions, as described in Table 3, encompass various elements that employees connect to the decency and decent behavior of their managers. For example, when describing examples of decent behavior that were classified in the Mutual Trust dimension, employees were quoting reliance, protection, and consistency among other behavioral highlights.

Findings from interviews were used as a starting point for the development of items of the new scale. The terminology from the literature review was researched to establish which concepts were encompassed and suitable for the item generation. The final set of items should be understandable and linked to the dimensions of interest. The resulting initial set of items had 151 items classified into 7 conceptual dimensions.

\subsection{Study 2: Theoretical analysis of generated items for perceived managerial decency scale}

Expert judges have been the most widely utilized tool for analyzing content validity (e.g., Uzunboylu \& Ozdamli 2011; Hardesty \& Bearden, 2004). Also, during the scale development process, not only expert opinions should be used, but also the opinions of the target population, which is not too common in previous studies.
However, it is the basis for content validity assessment (Morgado et al., 2017).

The validity, which is defined as the ability of an instrument to measure the properties of the construct under study (DeVon et al., 2007; Beck \& Gable, 2001) is a vital factor in developing or applying a measurement instrument. Scale developers often use different rules for determining which items to retain (e.g., Zaichkowsky, 1994; Netemeyer et al., 1996). Lynn (1986) states that content validity is the requirement for the next forms of validity and should be given the highest priority in the instrument development. Content validity, which is also called "logical validity" (Newman \& Pineda 2013), can be defined as the ability of the selected items to reflect variables of the measurement scale construct. It relates to the extent, to which the instrument items adequately represent the domain of the construct in focus.

In accordance with the aforementioned, a pilot research was carried out in Study 2 , in which the experts in the area of management and marketing assessed the item content validity and classified items into dimensions that presumably measure the established construct of managerial decency. The panel of experts who participated in the pilot research assessed the scale content validity for measuring managerial decency. 
The invitation for participation in the panel of experts was sent to 33 e-mail addresses (members of the business community managers of medium level of hierarchy and staff, and members of the academic community in the area of management and marketing), and 21 experts (5 from the academic community, and 16 from the business community) expressed interest to participate in the research. The interviewees were asked to assess to which of the seven dimensions a certain item belongs, and then to evaluate how significant (scale 1 - 7) the item is for that dimension.

The abovementioned corresponds with the Q-methodology (Q-Sort Method), which is a mixture of both qualitative-quantitative methods. This enables the assessment of the scale content validity and implies the procedure in which independent evaluators (experts), who are not familiar with the details of research, are asked to establish the level of the relative importance of each item in measuring the certain construct. Based on the data collected from experts (Table 4), the Content Validity Ratio of the construct is calculated. Thus, the experts are asked to state whether an item is necessary (important) for the construct administration within the item set or not. For that purpose, they were asked in this survey to assess each item on the scale, ranging from "completely unimportant" to "completely important". A higher score indicates further agreement of the expert committee about the necessity of the item in the measurement instrument. The formula of the content validity ratio is $\mathrm{CVR}=(\mathrm{Ne}-\mathrm{N} / 2) /(\mathrm{N} / 2)$, in which (Ne) represents the number of experts/ target group members who point to "important", and $\mathrm{N}$ is the total number of panelists. Lawshe (1975) proposed the formula for CVR calculation, according to which in further phases of a survey only items considered necessary by $50 \%$ of experts should be retained. An alternative manner of calculation of CVR indicators was proposed by Lewis (1995), according to whom those items considered irrelevant by $50 \%$ of experts should be eliminated $(C V R<0.5)$. The numeric value of the content validity ratio is determined by the Lawshe Table. For example, in our study the number of panelists is 21 members (5 experts from the academic community and 16 members of the target population), if CVR is bigger than 0.49 , the item in the instrument with an acceptable level of significance will bet accepted (Lawshe,1975).

In reports of instrument development, an additional measure of content validity is the content validity index CVI (Waltz et al., 2010; Davis, 1992). The formula of the item-level content validity index I-CVI = $\mathrm{Ne} / \mathrm{N}$, in which $(\mathrm{Ne})$ represents the number of experts/target group members who state that the item is relevant, and $\mathrm{N}$ is the total number of panelists. To obtain a content validity index for relevancy of each item (I-CVIs), the number of those judging the item as relevant (e.g., rating 5,6, or 7) was divided by the number of experts. Item Impact Score (IIS) is the third relevant measure for content validity, evaluated as the multiplicator of frequency and importance. The formula of the item impact score is IIS $=\mathrm{I}_{-} \mathrm{CVI}^{*} \overline{\mathrm{X}}$, in which I-CVI is calculated as described above, and $\bar{X}$ represents the average relevancy of an item as assessed by all target panelists. IIS is at the acceptable level if the score is equal or higher than 2 (which corresponds to an I-CVI of $50 \%$, multiplied by the average importance of 4 on a 7-point Likert scale).

Table 4 shows the content validity index value and the average value of the importance of the manifest variables from the initial set of manifest variables which fulfilled the two mentioned criteria for content 


\section{Journal of Contemporary Management Issues}

validity. Based on the analysis of content validity, the initial number of manifest variables (151) was reduced to 63 , and the initial number of dimensions (7) was reduced to 6 .

Taking into consideration that in addition to the individual item, the correct classification of the item in the previously given dimension was taken into account in the calculation of the content validity ratio (at least 3 of 5 experts from the academic community, and 8 of 16 experts from the business community) in order not to leave out the items assessed as relevant by experts although those were not added to the initially defined dimensions.

Table 4. Scores of perceived managerial decency scale content validity assessment - CVR

\begin{tabular}{|c|c|c|c|}
\hline Item & $\begin{array}{c}\text { CVR } \\
\text { (Academic Experts) }\end{array}$ & $\begin{array}{c}\text { CVR } \\
\text { (Managerial } \\
\text { Experts) }\end{array}$ & $\begin{array}{c}\bar{X} \\
\text { (Total) }\end{array}$ \\
\hline Supervisor appreciates my efforts. & 0.60 & 1.00 & 6.06 \\
\hline $\begin{array}{l}\text { Supervisor treats me as a person, not as } \\
\text { a number. }\end{array}$ & 1.00 & 0.88 & 6.00 \\
\hline Supervisor appreciates me as a person. & & 0.88 & 5.52 \\
\hline Supervisor treats me as an individual. & & 0.75 & 5.19 \\
\hline Supervisor values me as a person. & & 0.63 & 5.05 \\
\hline Supervisor treats me with respect. & & 1.00 & 6.00 \\
\hline Supervisor understands my needs. & & 0.75 & 5.15 \\
\hline $\begin{array}{l}\text { Supervisor expresses his/her view } \\
\text { without degrading others. }\end{array}$ & 1.00 & 0.88 & 5.81 \\
\hline $\begin{array}{l}\text { Supervisor behaves well in any } \\
\text { situation. }\end{array}$ & 0.60 & 0,50 & 5.00 \\
\hline $\begin{array}{l}\text { Supervisor uses decent language in } \\
\text { communication with me. }\end{array}$ & 0.60 & 0.63 & 5.48 \\
\hline Supervisor cares to dress appropriately. & 0.60 & 0.63 & 4.86 \\
\hline $\begin{array}{l}\text { Supervisor always greets me when we } \\
\text { meet. }\end{array}$ & 0.60 & 1.00 & 5.95 \\
\hline $\begin{array}{l}\text { Supervisor expresses disagreement } \\
\text { without being rude toward others. }\end{array}$ & 1.00 & 0.63 & 5.81 \\
\hline Supervisor avoids inappropriate jokes. & 1.00 & 0.50 & 4.86 \\
\hline $\begin{array}{l}\text { I feel appreciated when the supervisor is } \\
\text { civil toward me. }\end{array}$ & 0.60 & & 5.70 \\
\hline $\begin{array}{l}\text { Supervisor uses an appropriate tone in } \\
\text { conversation with me. }\end{array}$ & 0.60 & & 5.80 \\
\hline $\begin{array}{l}\text { Supervisor apologizes when s/he makes } \\
\text { a mistake. }\end{array}$ & 1.00 & & 5.43 \\
\hline $\begin{array}{l}\text { Supervisor is mindful in interactions } \\
\text { with me. }\end{array}$ & 0.60 & & 5.24 \\
\hline
\end{tabular}


Management, Vol. 26, 2021, No. 1, pp. 37-62 B. Hadžiomerović, E. Kurtić, M. Arslanagić-Kalajdžić: UNDERSTANDING THE DIMENSIONS OF ...

\begin{tabular}{|c|c|c|c|}
\hline Item & $\begin{array}{c}\text { CVR } \\
\text { (Academic Experts) }\end{array}$ & $\begin{array}{c}\text { CVR } \\
\text { (Managerial } \\
\text { Experts) }\end{array}$ & $\begin{array}{c}\bar{X} \\
\text { (Total) }\end{array}$ \\
\hline $\begin{array}{l}\text { Supervisor discusses with my private } \\
\text { life, within decency limits (e.g., family, } \\
\text { health). }\end{array}$ & 0.60 & & 4.62 \\
\hline Supervisor always calls me by my name. & & 0.63 & 4.71 \\
\hline $\begin{array}{l}\text { Supervisor is led by the example of } \\
\text { personal civil behavior. }\end{array}$ & & 0.50 & 5.00 \\
\hline $\begin{array}{l}\text { Supervisor is led by the example of } \\
\text { personal good manners. }\end{array}$ & & 0.50 & 5.09 \\
\hline $\begin{array}{l}\text { When entering a room, supervisor greets } \\
\text { all present people, regardless of their } \\
\text { status, profession, gender, and age. }\end{array}$ & & 0.88 & 5.62 \\
\hline $\begin{array}{l}\text { Supervisor uses a calm voice in } \\
\text { conversation with me. }\end{array}$ & & 0.75 & 5.38 \\
\hline $\begin{array}{l}\text { Supervisor always says "thank you" and } \\
\text { "please" when delegating tasks. }\end{array}$ & & 0.88 & 5.57 \\
\hline Supervisor is always punctual. & & 0.75 & 5.19 \\
\hline Supervisor maintains personal hygiene. & & 0.88 & 5.71 \\
\hline $\begin{array}{l}\text { Supervisor develops my skills to be able } \\
\text { to undertake more authorizations. }\end{array}$ & 0.60 & 0.75 & 6.00 \\
\hline $\begin{array}{l}\text { Supervisor motivates me to fully realize } \\
\text { my potentials, wishes, and needs. }\end{array}$ & 0.60 & 0.88 & 6.09 \\
\hline $\begin{array}{l}\text { Supervisor recognizes what I am best at } \\
\text { and delegates the task with which I can } \\
\text { best contribute to the team's success. }\end{array}$ & 1.00 & 0.88 & 5.86 \\
\hline $\begin{array}{l}\text { Supervisor offers me the opportunity for } \\
\text { development. }\end{array}$ & 0.60 & 0.75 & 6.15 \\
\hline Supervisor teaches me new things. & 0.60 & 0.88 & 5.91 \\
\hline $\begin{array}{l}\text { Supervisor supports me in performing } \\
\text { my tasks. }\end{array}$ & 0.60 & 0.75 & 5.81 \\
\hline $\begin{array}{l}\text { Supervisor creates a positive team } \\
\text { atmosphere. }\end{array}$ & 0.60 & & 5.86 \\
\hline $\begin{array}{l}\text { Supervisor helps in resolving problems, } \\
\text { which I cannot resolve on my own. }\end{array}$ & 0.60 & & 5.95 \\
\hline $\begin{array}{l}\text { Supervisor has proactive attitude toward } \\
\text { me and my job. }\end{array}$ & & 0.63 & 5.30 \\
\hline $\begin{array}{l}\text { Supervisor invests his/her personal } \\
\text { experience in work with me. }\end{array}$ & & 0.50 & 5.05 \\
\hline $\begin{array}{l}\text { Supervisor invests his/her time in work } \\
\text { with me. }\end{array}$ & & 0.63 & 5.38 \\
\hline
\end{tabular}


Journal of Contemporary Management Issues

\begin{tabular}{|c|c|c|c|}
\hline Item & $\begin{array}{c}\text { CVR } \\
\text { (Academic Experts) }\end{array}$ & $\begin{array}{c}\text { CVR } \\
\text { (Managerial } \\
\text { Experts) }\end{array}$ & $\begin{array}{c}\bar{X} \\
\text { (Total) }\end{array}$ \\
\hline $\begin{array}{l}\text { Supervisor creates energy and } \\
\text { enthusiasm among employees. }\end{array}$ & & 0.50 & 5.35 \\
\hline $\begin{array}{l}\text { Supervisor invests his/her energy in } \\
\text { work with me. }\end{array}$ & & 0.88 & 5.38 \\
\hline I have confidence in my supervisor. & 1.00 & 1.00 & 6.48 \\
\hline Supervisor trusts me. & 1.00 & 0.88 & 6.29 \\
\hline $\begin{array}{l}\text { I can rely on my supervisor in any } \\
\text { situation. }\end{array}$ & 1.00 & 1.00 & 6.33 \\
\hline $\begin{array}{l}\text { Supervisor completely trusts that I will } \\
\text { act as we agreed. }\end{array}$ & 1.00 & 0.88 & 6.24 \\
\hline $\begin{array}{l}\text { Supervisor trusts me to make better } \\
\text { judgments. }\end{array}$ & 0.60 & 0.50 & 5.25 \\
\hline $\begin{array}{l}\text { Supervisor clearly understands that my } \\
\text { mistakes are unintentional and are part } \\
\text { of everyday work and does not blame } \\
\text { me when they occur. }\end{array}$ & & 0.88 & 5.38 \\
\hline $\begin{array}{l}\text { When supervisor learns about the } \\
\text { "problem" s/he completely assumes } \\
\text { responsibility to resolve the problem. }\end{array}$ & & 0.50 & 4.80 \\
\hline $\begin{array}{l}\text { Supervisor has a frank relationship with } \\
\text { me. }\end{array}$ & & 0.88 & 5.57 \\
\hline $\begin{array}{l}\text { Supervisor is just in conflict situations } \\
\text { within a team. }\end{array}$ & & 0.75 & 5.86 \\
\hline $\begin{array}{l}\text { Supervisor supports me in difficult } \\
\text { situations. }\end{array}$ & & 0.75 & 5.55 \\
\hline Supervisor has just relationship with me. & & 0.88 & 5.75 \\
\hline $\begin{array}{l}\text { Supervisor delegates me authorizations } \\
\text { in addition to tasks because } \mathrm{s} / \text { he trust } \\
\text { me. }\end{array}$ & & 0.88 & 5.80 \\
\hline $\begin{array}{l}\text { My supervisor backs me in conflict } \\
\text { situations with the employees from } \\
\text { other sections. }\end{array}$ & & 0.63 & 5.67 \\
\hline $\begin{array}{l}\text { I can address my supervisor for any } \\
\text { problem. }\end{array}$ & & 0.50 & 5.19 \\
\hline $\begin{array}{l}\text { Supervisor consults me for any } \\
\text { important decisions in business } \\
\text { relationships. }\end{array}$ & & 0.50 & 5.09 \\
\hline Supervisor has no hidden agenda. & & 0.75 & 5.57 \\
\hline $\begin{array}{l}\text { Supervisor provides clear instructions } \\
\text { and deadlines for the completion of } \\
\text { tasks. }\end{array}$ & 0.60 & 0.88 & 6.05 \\
\hline
\end{tabular}




\begin{tabular}{|l|c|c|c|}
\hline Item & $\begin{array}{c}\text { CVR } \\
\text { (Academic Experts) }\end{array}$ & $\begin{array}{c}\text { CVR } \\
\text { (Managerial } \\
\text { Experts) }\end{array}$ & $\begin{array}{c}\text { X } \\
\text { (Total) }\end{array}$ \\
\hline $\begin{array}{l}\text { Supervisor provides an open explanation } \\
\text { when I make a mistake. }\end{array}$ & 0.60 & 0.88 & 6.09 \\
\hline $\begin{array}{l}\text { Supervisor openly indicates the problem } \\
\text { in a decent manner. }\end{array}$ & 0.60 & 0.88 & 5.62 \\
\hline $\begin{array}{l}\text { Supervisor timely provides feedback on } \\
\text { decision and its implications. }\end{array}$ & & 0.75 & 6.05 \\
\hline $\begin{array}{l}\text { Supervisor provides me information in a } \\
\text { way that I see the whole picture and my } \\
\text { role in that. }\end{array}$ & 1.00 & 0.75 & 5.48 \\
\hline $\begin{array}{l}\text { Supervisor timely informs me about the } \\
\text { objectives of the company. }\end{array}$ & & 0.75 & 5.71 \\
\hline $\begin{array}{l}\text { Supervisor timely informs me about } \\
\text { events. }\end{array}$ & & & 6.05 \\
\hline
\end{tabular}

Notes: $\mathrm{X}=$ arithmetic mean; Empty fields $=\mathrm{CVR}$ lower than 0.5

However, since CVR is the strict measure and it automatically assumes that CVI and IIS score criteria are satisfied, we aimed not to miss any potentially relevant item. Therefore, an additional set of items that were rated as important (with 5, 6, and 7) by all experts was assessed and included (see Table 5), as well as the ones with the IIS of 6 and 7 (see Table 6). For CVI (content validity index), the number of those judging the item as relevant or clear (rating 5,6 , or 7) was divided by the number of content experts. Hence, only the ones with a
$100 \%$ score were kept, while the IIS (item impact score) frequency is multiplied by the item importance, and the ones above 6 were kept.

Based on conducted additional analysis of the content validity by CVI and Item Impact Score, the number of manifest variables (63), increased by 12 items, was added to the scale, resulting in a total of 75 relevant items. In the Appendix, all retained items are summarized and listed by their respective dimension.

Table 5. Scores of perceived managerial decency scale content validity assessment - CVI

\begin{tabular}{|l|c|c|}
\hline Item & $\begin{array}{c}\text { CVI \% } \\
\text { (Academic } \\
\text { Experts) }\end{array}$ & $\begin{array}{c}\text { CVI \% } \\
\text { (Managerial } \\
\text { Experts) }\end{array}$ \\
\hline $\begin{array}{l}\text { Supervisor encourages team members to speak when they disagree with the } \\
\text { decision made. }\end{array}$ & 100 & 100 \\
\hline Decent pointing out of mistakes by supervisor motivates me to work better. & 100 & \\
\hline $\begin{array}{l}\text { Supervisor is focused on me in our conversation (e.g., does not use mobile } \\
\text { phone during conversation). }\end{array}$ & 100 & 100 \\
\hline Supervisor shows empathy in every-day work. & & 100 \\
\hline $\begin{array}{l}\text { Supervisor emphasizes that without each of us, without our individual } \\
\text { contributions, the overall success would not be possible. }\end{array}$ & & \\
\hline Supervisor is consistent in clarity and communication with me. & & \\
\hline
\end{tabular}




\section{Journal of Contemporary Management Issues}

Table 6. Scores of perceived managerial decency scale content validity assessment - IIS

\begin{tabular}{|c|c|c|}
\hline Item & $\begin{array}{c}\text { IIS } \\
\text { (Academic } \\
\text { Experts) }\end{array}$ & $\begin{array}{c}\text { IIS } \\
\text { (Managerial } \\
\text { Experts) }\end{array}$ \\
\hline Supervisor provides criticism of my work in private. & 6.0 & \\
\hline Supervisor has equal treatment of all employees. & 6.2 & \\
\hline Supervisor provides me full information necessary for my work. & 6.6 & \\
\hline Supervisor does not hide information from me. & 6.2 & \\
\hline Supervisor allows me to express my view to the end when I speak. & & 6.0 \\
\hline $\begin{array}{l}\text { Supervisor presents well short-term and long-term objectives and is aware } \\
\text { of the time necessary to achieve both of them. }\end{array}$ & & 6.2 \\
\hline
\end{tabular}

\section{CONCLUSIONS AND IMPLICATIONS}

\subsection{Theoretical implications}

According to the social exchange theory, embracing decency allows people to benefit from increasing connections and connectedness among people (Lawler, 2001). Such connections and communication with connectedness should be useful in motivating, influencing, and leading (Porath, Gerbasi, \& Schorch, 2015; Bennis, 1999; Kouzes \& Posner, 2011). Decent leaders encourage their employees and teams to improve the quality of their work relationships (Peterson, Smith, Martorana, \& Owens, 2003).

When organizations, or managers within organizations, provide evidence of "goodwill" towards employees, this creates the "commitment" of employees to reciprocate "good deed" (Gouldner 1960; Aryee et al., 2002). It has been generally observed that reciprocal behaviors (through reciprocity norm) exceed behaviors defined in contracts (Organ 1988; Tsui et al., 1997.). As such, positive social exchange may result in mutual benefits both for the employing organization and the workforce (Wayne et al., 1997). If employees positively see the management activities, they respond with attitudes and behaviors valued by the organization.

Based on our research, we define perceived managerial decency as the behavior that includes respectful interactions, treatment with good manners, and decent feedback, while the manager is focused on employee development, building mutual trust, and providing the employee with insight into a bigger picture. This definition encompasses six emergent dimensions of perceived managerial decency that are a result of the studies conducted. Those dimensions are (1) respectful interactions, (2) treatment with good manners, (3) employee development, (4) mutual trust, (5) decent feedback, (6) providing insight into a bigger picture. It can be seen that, apart from good manners and respect, decency includes relational concepts that are based on the SET, such as a mutual trust or decent feedback.

Decency represents "scenery" for obtaining benefits from mutual collaboration which improves performance. It has been shown that instrumental resources that decency offers are important for both sides of the relationships - employees who seek them (e.g., advice) but also the leaders who provide them (Porath, Gerbasi, \& Schorch, 2015; Grant, 2013; Pfeffer, 2010) by creating the feeling of obligation of the person 
who accepts advice and receives knowledge (Emerson, 1972). Positive emotions, which result from the fact that one is recognized and perceived as a person who gives advice and shares knowledge, create mutual relationships (Gouldner, 1960) which may improve work (Grant, 2013).

By offering an in-depth assessment of the decency concept through literature review, qualitative research, and expert ratings, we identified 75 items, reflecting 6 content dimensions of managerial decency. This result has strong theoretical implications, as this is a comprehensive overview of the scope and domain of decency construct in the work environment. which also sheds additional light on the importance of this construct for managers and practitioners. The measure is now ready for testing and empirical verification in various contexts, which will, consequently, mean its increased use both in research and practice.

\subsection{Managerial implications}

In terms of managerial implications, this study aims to draw the attention of managers to the relevance of the decency construct in successful leadership. Namely, due to its specific aspects which can often be considered as "weaknesses", managers often neglect decency in their communications and their quest for power.

However, in this study, we demonstrate that employees do recognize decency with its complex dimensionality and that it is a relevant and worthy aspect of consideration. It still needs to be determined whether decency contributes to the success of managers, as well as to the wellbeing and satisfaction of employees in organizations. By measuring decency, we should be able to conclude whether it represents an aspect of leadership and management that builds bridges between colleagues and produces a comfortable sense of community (Harrsion, 2007).

\subsection{Limitations and further research}

This study is not without its limitations. Primarily, the context of the scale development is placed in only one country/setting. It should be further assessed whether the content validity achieved would yield the same results across different countries and cultures. Furthermore, since there is no empirical validation of the proposed scale yet, it cannot be connected to another vital construct of the workplace environment (such as job satisfaction or turnover intentions) which is an avenue for future research. Finally, it should be further distinguished that civility is not the same as decency, since current research streams are indeed using this construct interchangeably.

Further research should stress the discriminant validity procedure for the development of the decency scale and ensure that all similar but not fully related constructs (such as civility, trust in leader, and organizational justice dimensions) are included in the assessment of the validity of the scale. Also, further research should ensure that there is sufficient difference among them and their dimensions and the dimensions of decency. Such research would need to include a rigorous quantitative assessment of validity and reliability.

\section{REFERENCES}

1. Agervold, M., \& Mikkelsen, E. G. (2004). Relationships between bullying, psychosocial work environment and individual stress reactions. Work \& Stress, 18(4), 336-351.

2. Anderson, L. M., \& Pearson, C. M. (1999). Tit for tat? The spiraling effect 


\section{Journal of Contemporary Management Issues}

of incivility in the workplace. Academy of Management Review, 24, 452-471.

3. Arias, M. R. M., Lloreda, M. J. H., \& Lloreda, M. V. H. (2014). Psicometría. S.A.: Alianza Editorial

4. Aryee, S., Budhwar, P. S., \& Chen, Z. $X$. (2002). Trust as a mediator of the relationship between organizational justice and work outcomes: Test of a social exchange model. Journal of Organizational Behavior, 23, 267-286.

5. Ashforth, B. (1997). Petty Tyranny in organizations: A preliminary exarnination of antecedents and consequences. Canadian Journal of Administrative Sciences, 14, 126- 140.

6. Beck, C. T., \& Gable, R. K. (2001). Ensuring content validity: An illustration of the process. Journal of Nursing Measurement, 9(2), 201-215.

7. Bennis, W. (1999). Managing people is like herding cats. Provo, UT: Executive Excellence Publishing.

8. Bies R.J, \& Tripp T.M (2005). The study of Revenge in the Workplace:Conceptual, Ideological and Empirical Issues. American Psychological Association

9. Blustein, D. L. (2011). A relational theory of working. Journal of Vocational Behavior, 79, 1-17

10. Blustein, D. L., Olle, C., ConnorsKellgrem, A., \& Diamonti, A. J. (2016). Decent work: a psychological perspective. Frontiers in Psychology, 7:407.

11. Boulding, B. (2019). For Leaders, Decency Is Just as Important as Intelligence. Harvard Business Review (July, 2019) Available at: https://hbr. org/2019/07/for-leaders-decency-isjust-as-important-as-intelligence.
12. Carter, S. L. (1998). Civility: Manners, Morals, and the Etiquette of Democracy. New York, NY: Basic Books.

13. Clark, C. M. \& Landrum, R. E., \& Nguyen, D. (2013). Development and description of the Organizational Civility Scale (OCS). Journal of Theory Construction and Testing, 17(1), 11 - 17

14. Colquitt, J. A. (2001). On the dimensionality of organizational justice: a construct validation of a measure. Journal of Applied Psychology, 86(3), 386.

15. Colquitt, J. A., Scott, B. A., Rodell, J. B., Long, D. M., Zapata, C. P., Conlon, D. E., \& Wesson, M. J. (2013). Justice at the millennium, a decade later: a meta-analytic test of social exchange and affect-based perspectives. Journal of Applied Psychology, 98(2), 199.

16. Cooley, C. H. (1902). Human nature and the social order. New York, NY: Scribners.

17. Cortina, L. M. (2008). Unseen injustice: Incivility as modern discrimination in organizations. Academy of Management Review, 33(1), 55-75.

18. Cortina, L. M., Magley, V. J., Williams, J. H., \& Langhout, R. D. (2001). Incivility in the workplace: Incidence and impact. Journal of Occupational Health Psychology, 6, 64-80.

19. Crocker, R.M. (2005). Employee perceptions of managerial civility: Development and validation of a measurement scale, Doctoral Dissertation, Auburn University.

20. Cropanzano, R., \& Mitchell, M. S. (2005). Social exchange theory: An interdisciplinary review. Journal of Management, 31(6), 874-900. 
21. Davis LL. (1992). Instrument review: Getting the most from a panel of experts. Applied Nursing Research, 5(4), 194-197.

22. Di Fabio, A., \& Gori, A. (2016). Assessing workplace relational civility (WRC) with a new multidimensional "mirror" measure. Frontiers in Psychology, 7: 890.

23. Di Fabio, A., \& Kenny, M. E. (2016). From decent work to decent lives: positive self and relational management (PS\&RM) in the Twenty-First Century. Frontiers in Psychology, 7:361.

24. DeVellis, R.F. (2003). Scale development: theory and applications, applied social research methods. Sage Publications. Thousand Oaks. 1-216.

25. DeVon, H. A., Block, M. E., MoyleWright, P., Ernst, D. M., Hayden, S. J., Lazzara, D. J., ... \& Kostas-Polston, E. (2007). A psychometric toolbox for testing validity and reliability. Journal of Nursing Scholarship, 39(2), 155-164.

26. Dutton, J. E. (2003). Energize your workplace: How to build high quality connections at work. San Francisco, CA: Jossey-Bass.

27. Elias (1982). Power and Civility: The Civilizing Process., Vol. 2. (New York, Pantheon Books)

28. Emerson, R. (1972). Exchange theory part I: A psychological basis for social exchange. In J. Berger, M. Zelditch, \& B. Anderson (Eds.), Sociological theories in progress (pp. 38-57). Boston, MA: Houghton Mifflin.

29. Faioli, M. (2009). Decency at Work: Dalla tensione del lavoro alla Dignità. Categorie interculturali e sapere giuridico.

30. Ferris, A. L. (2002). Studying and measuring civility: A framework, trends and scale. Sociological Inquiry, 72(3), 376-392.

31. Forni, P. M. (2002). Choosing civility: The twenty-five rules of considerate conduct. New York, NY: St. Martin's Press Griffin.

32. Gouldner, A. W. (1960). The norm of reciprocity: A preliminary statement. American Sociological Review, 25, 161-178.

33. Grant, A. M. (2013). Give and take: A revolutionary approach to success. New York, NY: Viking Press.

34. Greenberg, J. (1990). Organizational justice: Yesterday, today, and tomorrow. Journal of management, 16(2), 399-432.

35. Griffin, R. W., Stoverink, A. C., \& Gardner, R. G. (2012). Negative interpersonal exchanges in teams. In L. Eby \& T. Allen (Eds.), Personal relationships: The effect on employee attitudes, behavior, and well-being (pp. 131156). New York, NY: Routledge.

36. Hallowell, E. M. (1999). Connect: 12 vital ties that open your heart, lengthen your life, and deepen your soul. New York, NY: Pocket Books.

37. Harrison, S. G. (2007). The Manager's Book of Decencies: How Small Gestures Build Great Companies. McGraw Hill Professional.

38. Hardesty, D. M., \& Bearden, W. O. (2004). The use of expert judges in scale development: Implications for improving face validity of measures of unobservable constructs. Journal of Business Research, 57(2), 98-107.

39. Heller, A. (1990). A Philosophy of Morals. Oxford: Blackwell

40. Herzberg, F., Mausner, B., \& Snyderman, B. B. (1959). The motivation to work. New York: John Wiley. 


\section{Journal of Contemporary Management Issues}

41. Hinkin, T. R. (1995). A review of scale development practices in the study of organizations. Journal of Management, 21(5), 967-988.

42. Hutz, CS, Bandeira, DR, \& Trentini, CM. (Org.). (2015). Psicometria. Porto Alegre, Artmed

43. Judge, T. A., Livingston, B. A., \& Hurst, C. (2012). Do nice guys - and gals - really finish last? The joint effects of sex and agreeableness on income. Journal of Personality and Social Psychology, 102, 390-407.

44. Kimbrough, R.B \& Burkett, C.W. (1990).The Principalship: Concepts and Practices. Prentice Hall.

45. Kouzes, J. M., \& Posner, B. (2011). Credibility: How leaders gain and lose it, why people demand it (2nd ed.). San Francisco, CA: Jossey-Bass.

46. Lawler, E. J. (2001). An affect theory of social exchange. American Journal of Sociology, 107, 321-352

47. Lawshe, C. H. (1975). A quantitative approach to content validity. Personnel Psychology, 28(4), 563-575.

48. Leiter, M. P., Laschinger, H. K. S., Day, A., \& Oore, D. G. (2011). The impact of civility interventions on employee social behavior, distress, and attitudes. Journal of Applied Psychology, 96(6), 1258-1274.

49. Leiter, M. P., \& Maslach, C. (2009). Nurse turnover: the mediating role of burnout. Journal of Nursing Management, 17(3), 331-339.

50. Lim, S., Cortina, L. M., \& Magley, V. J. (2008). Personal and workgroup incivility: Impact on work and health outcomes. Journal of Applied Psychology, 93, 95-107.

51. Lynn, M. R. (1986). Determination and quantification of content validity. Nursing research. 35 , 382-385

52. Macklin, R. (2007). The morally decent HR manager. Human resource management: Ethics and employment, 266. Oxford University Press

53. Martin, R. \& Hine, D. (2005). Development and validation of the Uncivil Workplace Behavior Questionnaire. Journal of Occupational Health Psychology. 10. 477-90

54. McNamee, G. (2018). Civility vs. Decency. VQR, Volume 94; \#3

55. Meck, T. (2020). What to Expect In The Future Of Corporate Communications . Forbes Communications Council

56. Meterko, M., Osatuke, K., Mohr, D., Warren, N., \& Dyrenforth, S. (2007). Civility: The development and psychometric assessment of a review measure. Paper presented at the Academy of Management, Philadelphia, PA.

57. Moorman, R. H. (1991). Relationship between organizational justice and organizational citizenship behaviors: Do fairness perceptions influence employee citizenship?. Journal of Applied Psychology, 76(6), 845.

58. Morgado, F.F.R., Meireles, J.F.F., Neves, C.M., Amaral, A.C.S, \& Ferreira, M.E.C. (2017). Scale development: ten main limitations and recommendations to improve future research practices. Psicologia: Reflexão e Crítica, 30, 3, 1-20. Psicologia: Reflexão e Crítica

59. Muñoz-Leiva, F., Sánchez-Fernández, J., Liébana-Cabanillas, F. J., \& LópezHerrera, A. G. (2012). Applying an automatic approach for showing up the hidden themes in financial marketing research (1961-2010). Expert 
Systems with Applications, 39(12), 11055-11065.

60. Netemeyer, R.G., Boles, J.S., \& McMurrian, R. (1996). Development and Validation of Work-Family Conflict and Family-Work Conflict Scales, Journal of Aplied Psychology, 8(4), 400-410

61. Newman, I., Lim, J., \& Pineda, F. (2013). Content validity using a mixed methods approach: Its application and development through the use of a table of specifications methodology. Journal of Mixed Methods Research, 7(3): 243-60.

62. Nunnally, J. C. (1967). Psychometric theory. New York: McGraw Hill.

63. Organ, D. W. (1988). Organizational citizenship behavior: The good soldier syndrome. Lexington, MA: Lexington Books.

64. Ottinot, R. C (2008). The Development and Validation of the Perceived Workplace Civility Climate Scale, Graduate Theses and Dissertations. Available at: .https://scholarcommons. usf.edu/etd/439

65. Paulin, D. \& Griffin, B. (2015) Team Incivility Climate Scale: Development and Validation of the Team-Level Incivility Climate Construct. Group \& Organization Management. 42(3):315-345.

66. Pearson, C. M. \& C. L. Porath (2005). On the Nature, Consequences, and Remedies of Workplace Incivility: No Time for "Nice"? Think Again. The Academy of Management Executive, 19, 7-18.

67. Pearson, C., Andersson, L., \& Porath, C. (2005). Workplace incivility. In P. Spector \& S. Fox (Eds.), Counterproductive workplace behavior: Investigations of actors and targets (pp. 256-309). Washington, DC: American Psychological Association.

68. Pearson, C. M., \& Porath, C. L. (2009). The cost of bad behavior: How incivility ruins your business-And what you can do about it. New York, NY: Penguin Group.

69. Peterson, R. S., Smith, D. B., Martorana, P. V., \& Owens, P. D. (2003). The impact of chief executive officer personality on top management team dynamics: One mechanism by which leadership affects organizational performance. Journal of Applied Psychology, 88, 795-808.

70. Pfeffer, J. (2013). You're still the same: Why theories of power hold over time and across contexts. The Academy of Management Perspectives, 27, 269 -280 .

71. Porath, C. L., Gerbasi, A., \& Schorch, S. L. (2015). The effects of civility on advice, leadership, and performance. Journal of Applied Psychology, 100(5), 1527-1541.

72. Porath, C. L., \& Pearson, C. M. (2012). Emotional and behavioral responses to workplace incivility and the impact of hierarchical status. Journal of Applied Social Psychology, 42(Supp. 1), E326-E357.

73. Porath, C. L., \& Erez, A. (2007). Does rudeness really matter? The effects of rudeness on task performance and helpfulness. Academy of Management Journal, 50, 1181-1197.

74. PWC PricewaterhouseCoopers (2021) The future of work: A journey to 2022

75. Quine, L. (2001). Workplace Bullying in Nurses. Journal of Health Psychology, $6 . \quad 73-84$. 10.1177/135910530100600106.

76. Roberts, L. M. (2007). From proving to becoming: How positive relationships 


\section{Journal of Contemporary Management Issues}

create a context for self-discovery and self-actualization. In J. Dutton \& B. Ragins (Eds.), Exploring positive relationships at work (pp. 29-45). Mahwah, NJ: Erlbaum.

77. Scarlicki, D. P., \& Folger, R. (1997). Retaliation in the workplace: The roles of distributive, procedural and interactional justice. Journal of Applied Psychology, 82, (3), 434-443.

78. Schein, E. H. (1978). Career dynamics: matching individual and organisational needs. Addison-Wesley Reading.

79. Tepper, B. (2000). Consequences of Abusive Supervision. Academy of Management Journal, 43. 178-190.

80. Trojak, N. \& Galić, Z. (2020). How to select a true leader? Introducing methods for measurement of implicit power motive. Management, 25 (1), 235-253.

81. Tsui, A. S., Pearce, J. L., Porter, L. W., \& Tripoli, A. M. (1997). Alternative approaches to the employee-organization relationship: Does investment in employees pay off? Academy of Management Journal, 40: 1089-1121.

82. Uzunboylu, H., \& Ozdamli, F. (2011). Teacher perception for m-learning: scale development and teachers' perceptions. Journal of Computer Assisted Learning, 27, 544-556

83. Walsh, B. M., Magley, V. J., Reeves, D. W., Davies-Schrils, K. A., Marmet, M. D., \& Gallus, J. A. (2012). Assessing workgroup norms for civility: The development of the Civility Norms Questionnaire-Brief. Journal of Business and Psychology, 27(4), 407-420

84. Waltz, C.F., Strickland, O. \& Lenz, E.R. (2010). Measurement in nursing and health research. $4^{\text {th }}$ ed. New York: Springer Publishing Company.

85. Weber Shandwick (2013). Civility in America 2013: Incivility has reached crisis levels. Retrieved from http:// www.webershandwick.com/news/article/civility-in-america-2013-incivilityhas-reached-crisis-levels

86. Yamada, D. C. (2000). The phenomenon of workplace bullying and the need for status-blind hostile work environment protection. Georgetown Law Journal, 88

87. Zaichkowsky, J. L. (1994). The Personal Involvement Inventory: Reduction, revision, and application to advertising. Journal of Advertising, 23(4), 5970 


\title{
RAZUMIJEVANJE DIMENZIJA KONSTRUKTA MENADŽERSKE PRISTOJNOSTI
}

\begin{abstract}
Sažetak
Ovim se radom pokušava unaprijediti razumijevanje percipirane menadžerske pristojnosti, razvojem inicijalnog skupa čestica za kreiranje mjerne ljestvice. Na temelju teorije društvene razmjene, kao i snažne potrebe za uključivanjem više razine pristojnosti $i$ ljubaznosti $u$ diskurs menadžmenta, u radu se izlaže opsežan pregled područja $i$ obuhvata percipirane menadžerske pristojnosti te se identificiraju njene potencijalne dimenzije. Nakon provedenog pregleda literature, kroz intervjue je prikupljeno 50 tipičnih primjera menadžerske pristojnosti, kako je percipiraju zaposlenici te su isti korišteni kao osnovica za daljn-

i 16 iz ciljne populacije), koristeći kvalitativne $i$ kvantitativne pristupe. Kao rezultat provedene analize, definirali smo konstrukt percipirane menadžerske pristojnosti i opisali njegovih šest potencijalnih dimenzija: (1) poštovanje u interakcijama, (2) dobro ponašanje prema drugima, (3) razvoj zaposlenika, (4) međusobno povjerenje, (5) pristojno pružanje povratnih informacija i (6) pružanje uvida u širu sliku. Također smo generirali skupinu 75 validnih čestica, koje reflektiraju konstrukt pristojnosti. Nadalje, raspravljamo o implikacijama provedenog istraživanja za teoriju i praksu.
\end{abstract} ju analizu. Korištenjem alata za analizu sadržaja, generirali smo inicijalnu skupinu čestica i dimenzija menadžerske pristojnosti. Njih je, nadalje, analizirao 21 ekspert (5 iz akademske zajednice
Ključne riječi: menadžerska pristojnost, kvalitativno istraživanje, razvoj mjerne skale 


\section{Journal of Contemporary Management Issues}

\section{APPENDIX: PERCEIVED MANAGERIAL DECENCY - PROPOSED CONTENT AND SCOPE}

\begin{tabular}{|c|c|}
\hline Dimension & Item \\
\hline \multirow{10}{*}{$\begin{array}{l}\text { Respectful interac- } \\
\text { tions }\end{array}$} & Supervisor appreciates my efforts. \\
\hline & Supervisor treats me as a person, not as a number. (adapted from Cortina et al., 2001) \\
\hline & Supervisor shows empathy in every-day work. \\
\hline & Supervisor appreciates me as a person. \\
\hline & $\begin{array}{l}\text { Supervisor emphasizes that without each of us, without our individual contributions, } \\
\text { the overall success would not be possible. }\end{array}$ \\
\hline & Supervisor treats me as an individual. (adapted from Ashforth, 1997) \\
\hline & Supervisor values me as a person. \\
\hline & Supervisor treats me with respect. (adapted from Moorman, 1991) \\
\hline & Supervisor allows me to express my view to the end when I speak. \\
\hline & Supervisor understands my needs. \\
\hline \multirow{21}{*}{$\begin{array}{l}\text { Treatment with good } \\
\text { manners }\end{array}$} & $\begin{array}{l}\text { Supervisor expresses his/her view without degrading others. (adapted from Di Fabio \& } \\
\text { Gori, 2016) }\end{array}$ \\
\hline & Supervisor behaves well in any situation. \\
\hline & Supervisor uses decent language in communication with me. \\
\hline & Supervisor cares to dress appropriately. \\
\hline & Supervisor always greets me when we meet. \\
\hline & $\begin{array}{l}\text { Supervisor expresses disagreement without being rude toward others. (adapted from Di } \\
\text { Fabio \& Gori, 2016) }\end{array}$ \\
\hline & Supervisor avoids inappropriate jokes. \\
\hline & I feel appreciated when the supervisor is decent toward me. \\
\hline & Supervisor uses appropriate tone in conversation with me. \\
\hline & Supervisor apologizes when s/he makes a mistake. \\
\hline & Supervisor is mindful in interactions with me. \\
\hline & Supervisor discusses with me private life, within decency limits (e.g., family, health). \\
\hline & $\begin{array}{l}\text { Supervisor is focused on me in our conversation (e.g., does not use mobile phone } \\
\text { during conversation). }\end{array}$ \\
\hline & Supervisor always calls me by my name. \\
\hline & Supervisor is led by the example of personal decent behaviour. \\
\hline & Supervisor is led by the example of personal good manners. \\
\hline & $\begin{array}{l}\text { When entering a room, supervisor greets all present persons regardless of their status, } \\
\text { profession, gender and age. }\end{array}$ \\
\hline & Supervisor uses calm voice in conversation with me. \\
\hline & Supervisor always says "thank you" and "please" when delegating tasks. \\
\hline & Supervisor is always punctual. \\
\hline & Supervisor maintains personal hygiene. \\
\hline
\end{tabular}




\begin{tabular}{|c|c|}
\hline \multirow{18}{*}{$\begin{array}{l}\text { Employee } \\
\text { development }\end{array}$} & Supervisor develops my skills to be able to undertake more authorisations. \\
\hline & Supervisor motivates me to fully realise my potentials, wishes and needs. \\
\hline & $\begin{array}{l}\text { Supervisor recognizes what I am best at and delegates the task with which I can best } \\
\text { contribute to the team success. }\end{array}$ \\
\hline & Supervisor offers me the opportunity for development. \\
\hline & Supervisor teaches me new things. \\
\hline & Supervisor provides me support in performing my tasks. \\
\hline & Supervisor creates a positive team atmosphere. \\
\hline & Supervisor helps in resolving problems which I cannot resolve on my own. \\
\hline & $\begin{array}{l}\text { Supervisor encourages team members to speak when they disagree with the decision } \\
\text { made. (adapted from Ashforth, 1997) }\end{array}$ \\
\hline & Decent pointing out of mistakes by Supervisor motivates me to work better. \\
\hline & Supervisor has equal treatment of all employees. \\
\hline & Supervisor has proactive attitude toward me and my job. \\
\hline & Supervisor invests his/her personal experience in work with me. \\
\hline & Supervisor invests his/her time in work with me. \\
\hline & Supervisor creates energy and enthusiasm among employees. \\
\hline & Supervisor is consistent in clarity and communication with me. \\
\hline & $\begin{array}{l}\text { Supervisor presents well short-term and long-term objectives and is aware of the time } \\
\text { necessary to achieve both of them. }\end{array}$ \\
\hline & Supervisor invests his/her energy in work with me. \\
\hline \multirow{16}{*}{$\begin{array}{l}\text { Mutual } \\
\text { trust }\end{array}$} & I have confidence in my supervisor. \\
\hline & Supervisor trusts me. (adapted from Clark et al., 2013) \\
\hline & I can rely on my supervisor in any situation. \\
\hline & Supervisor completely trusts that I will act as we agreed. \\
\hline & Supervisor trusts me in order to make better judgements. \\
\hline & $\begin{array}{l}\text { Supervisor clearly understands that my mistakes are unintentional and are part of } \\
\text { every-day work and does not blame me when they occur. }\end{array}$ \\
\hline & $\begin{array}{l}\text { When supervisor learns about the "problem" s/he completely assumes responsibility to } \\
\text { resolve the problem. }\end{array}$ \\
\hline & Supervisor has frank relationship with me. (adapted from Moorman, 1991) \\
\hline & Supervisor is just in conflict situations within a team. \\
\hline & Supervisor supports me in difficult situations. \\
\hline & Supervisor has just relationship with me. \\
\hline & Supervisor delegates me authorisations in addition to tasks because s/he trust me. \\
\hline & My supervisor backs me in conflict situations with the employees from other sections. \\
\hline & I can address my supervisor for any problem. \\
\hline & Supervisor consults me for any important decision in business relationships. \\
\hline & Supervisor has no hidden agenda. \\
\hline
\end{tabular}




\section{Journal of Contemporary Management Issues}

\begin{tabular}{|l|l|}
\hline \multirow{4}{*}{$\begin{array}{l}\text { Decent } \\
\text { feedback }\end{array}$} & Supervisor provides clear instructions and deadlines for completion of tasks. \\
\cline { 2 - 3 } & Supervisor provides open explanation when I make a mistake. \\
\cline { 2 - 3 } Providing insight & Supervisor openly indicates the problem in a decent manner. \\
\cline { 2 - 3 } into a bigger picture & Supervisor provides criticism of my work in private. \\
\cline { 2 - 3 } & $\begin{array}{l}\text { Supervisor timely provides feedback on decision and its implications. (adapted from } \\
\text { Moorman, 1991) }\end{array}$ \\
\cline { 2 - 2 } & $\begin{array}{l}\text { Supervisor provides me information in a way that I see the whole picture and my role } \\
\text { in that. }\end{array}$ \\
\cline { 2 - 3 } & Supervisor provides me full information necessary for my work. \\
\cline { 2 - 3 } & Supervisor does not hide information from me. \\
\cline { 2 - 3 } & Supervisor timely informs me about the objectives of the company. \\
\cline { 2 - 3 } & Supervisor timely informs me about events. \\
\hline
\end{tabular}

